\title{
CyberShip-loT: A Dynamic and Adaptive SDN-Based Security Policy Enforcement Framework for Ships
}

Sahay, Rishikesh; Meng, Weizhi; Sepúlveda Estay, Daniel Alberto; Jensen, Christian D.; Barfod, Michael Bruhn

\section{Published in:}

Future Generation Computer Systems

Link to article, DOI:

10.1016/j.future.2019.05.049

Publication date:

2019

Document Version

Publisher's PDF, also known as Version of record

Link back to DTU Orbit

Citation (APA):

Sahay, R., Meng, W., Sepúlveda Estay, D. A., Jensen, C. D., \& Barfod, M. B. (2019). CyberShip-loT: A Dynamic and Adaptive SDN-Based Security Policy Enforcement Framework for Ships. Future Generation Computer Systems, 100, 736-750. https://doi.org/10.1016/j.future.2019.05.049

\section{General rights}

Copyright and moral rights for the publications made accessible in the public portal are retained by the authors and/or other copyright owners and it is a condition of accessing publications that users recognise and abide by the legal requirements associated with these rights.

- Users may download and print one copy of any publication from the public portal for the purpose of private study or research.

- You may not further distribute the material or use it for any profit-making activity or commercial gain

- You may freely distribute the URL identifying the publication in the public portal 


\title{
Corrigendum
}

\section{Corrigendum to "CyberShip-IoT: A Dynamic and Adaptive SDN-Based Security Policy Enforcement Framework for Ships” [Future Gener. Comput. Syst. 100 (2019) 736-750]}

\author{
Rishikesh Sahay ${ }^{\text {a }}$, Weizhi Meng ${ }^{\text {a,*, D.A. Sepulveda Estay }}{ }^{\mathrm{b}}$, Christian D. Jensen ${ }^{\mathrm{a}}$, Michael \\ Bruhn Barfod ${ }^{\mathrm{b}}$ \\ ${ }^{a}$ Department of Applied mathematics and Computer Science, Technical University of Denmark, DK-2800 kgs., Lyngby, Denmark \\ ${ }^{\mathrm{b}}$ Department of Management Engineering, Technical University of Denmark, DK-2800 kgs., Lyngby, Denmark
}

\section{A R T I C L E I N F O}

\section{Article history:}

Available online $\mathrm{xxxx}$

The authors regret to inform that some small issues are found on two figures $\sim$ Figs. 8 and 9 , and attach our new figures as below. The main differences are described as follows:

(a) Experimentation is conducted for a short time (180 s)

(b) Attack traffic is launched at $30 \mathrm{~s}$.

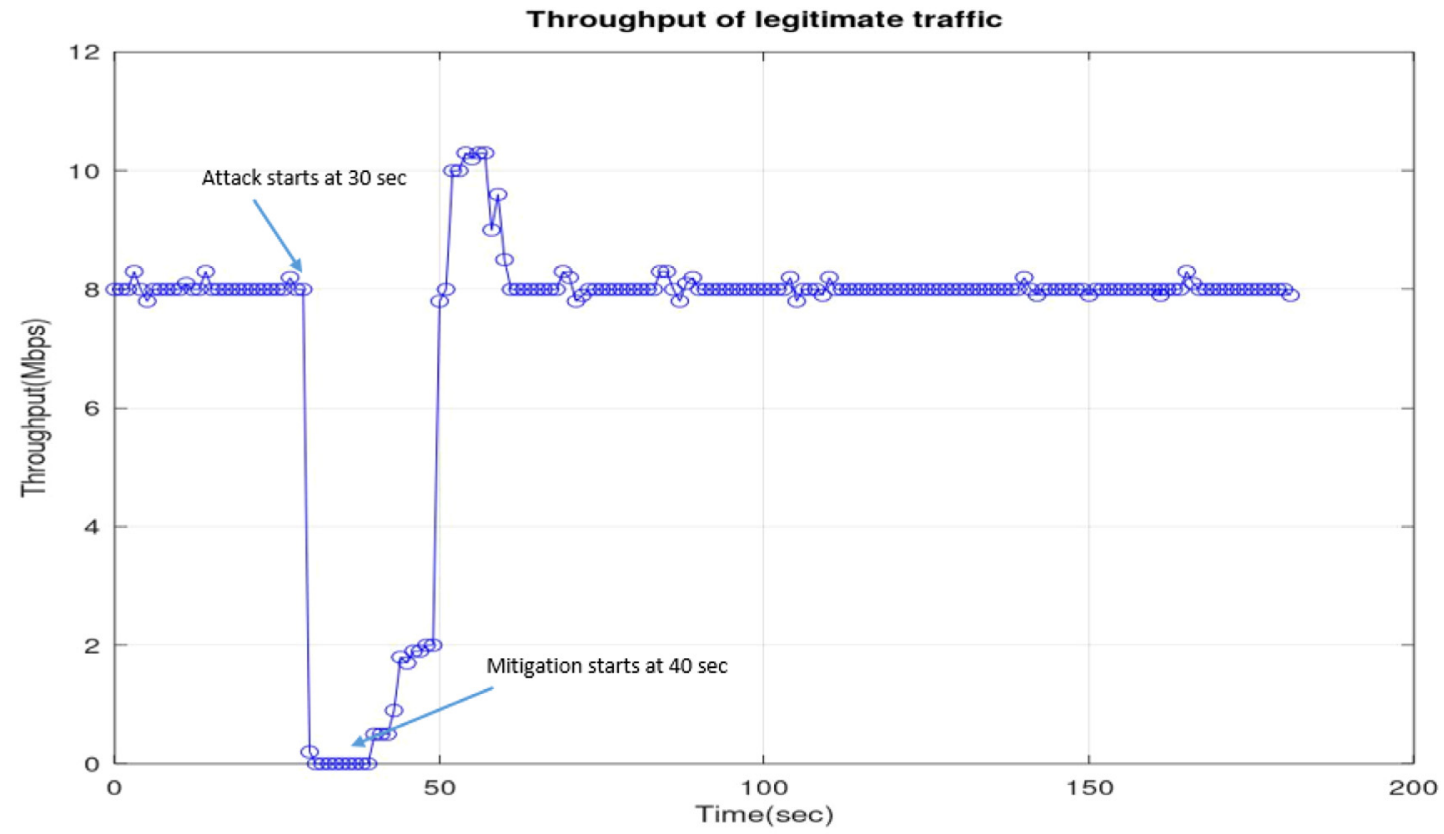

(c) Mitigation starts at $40 \mathrm{~s}$.

(d) Legitimate traffic is completely recovered at around $50 \mathrm{~s}$

Fig. 8.

DOI of original article: https://doi.org/10.1016/j.future.2019.05.049.

* Corresponding author.

E-mail address: weme@dtu.dk (W. Meng). 


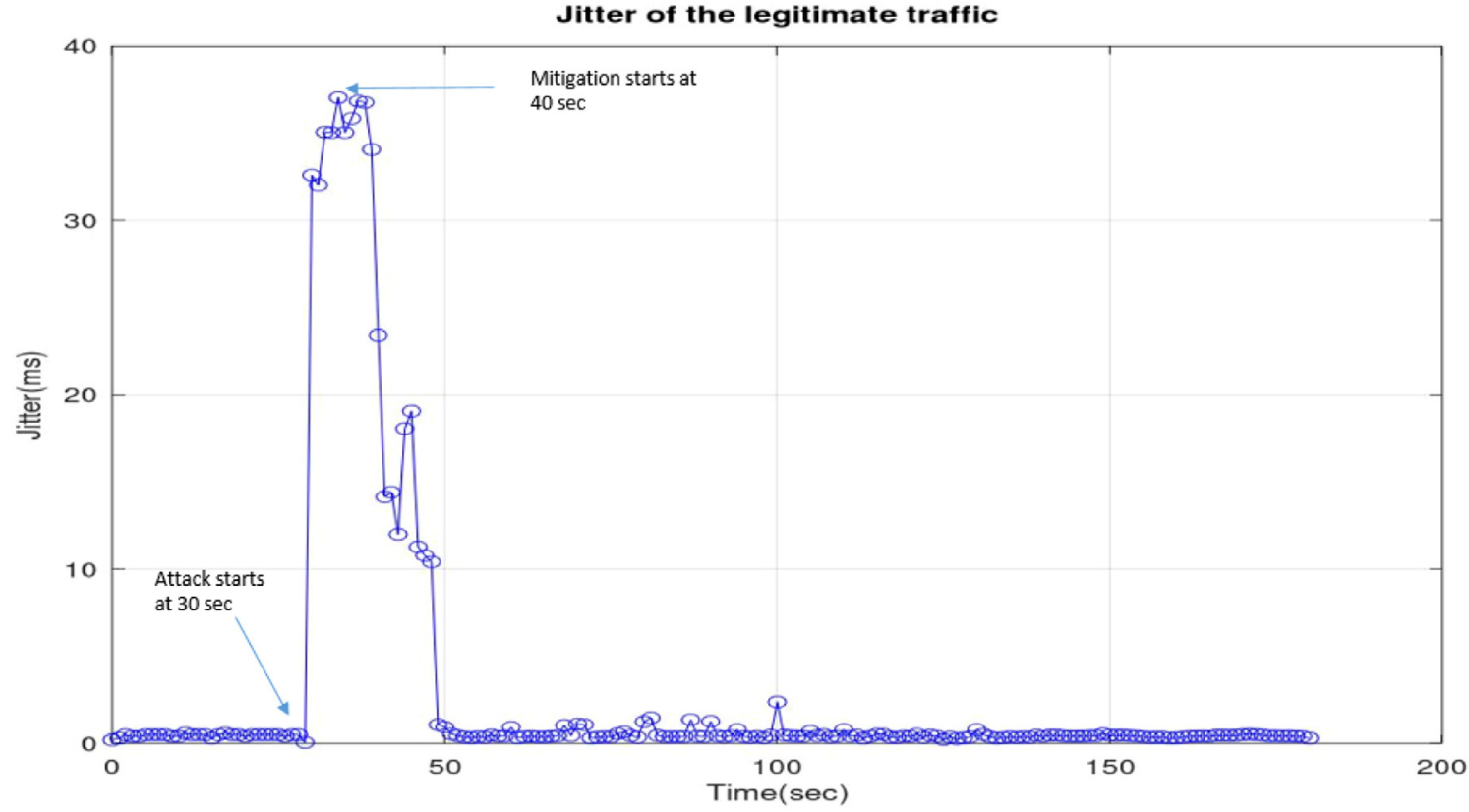

Fig. 9.

The authors would like to apologize for any inconvenience caused. 